\title{
Hospitalizations for conditions susceptible to primary care among children and adolescents in Minas Gerais, Brazil, 1999-2007
}

Lílian Amaral Santos 1

Veneza Berenice de Oliveira 2

Antônio Prates Caldeira 3

\footnotetext{
1,3 Universidade Estadual de Montes Claros. Campus Darcy Ribeiro. Av. Dr. Rui Braga, s.n. Vila Mauricéia. Montes Claros, MG, Brasil. CEP: 39.401-089. E-mail: antonio.caldeira@unimontes.br

2 Universidade Federal de Minas Gerais. Belo Horizonte, MG, Brasil.
}

\begin{abstract}
Objectives: to describe the evolution of rates of Hospitalizations for Conditions Susceptible to Primary Care (HCSPCS) in children and adolescents in Minas Gerais, testing the correlation with population coverage of the Family Health Strategy (FHS).

Methods: an ecological study analyzing the evolution over time and correlation with rates of coverage of the FHS between 1999 and 2007. Analyses were carried out for three age groups: 0 - 4 years, 5 - 9 years and 10 - 19 years. Pearson's correlation coefficient was used with a level of significance of $5 \%$.

Results: the rates of HCSPAs were found to decline during the period studied. In the population aged 0 - 4 years, a decrease of $19.1 \%$ was observed. For the 5 - 9 and $10-19$ year age groups, the rates fell by $0.6 \%$ and $18.5 \%$ respectively. There was no significant correlation between the decline in rates and increased FHS coverage. The main causes of hospitalization for all age groups were infectious gastroenteritis, bacterial pneumonia and asthma.

Conclusions: despite the decrease observed, the lack of correlation between coverage and rates of HCSPA draws attention to the need for improvement in access to and better professional qualification for child and adolescent healthcare.

Key words Primary healthcare, Hospitalization, Child health, Adolescent
\end{abstract}




\section{Introduction}

The Family Health Strategy (FHS) has been embarked on as a proposal for re-organizing the Brazilian health system, replacing the traditional hospital-centered model of care based on curative activities. ${ }^{1}$ Apart from bringing with them the guidelines of the Brazilian National Health System (SUS), of universality, equality and integral care, FHS teams must also incorporate primary contact, longitudinality and coordination of healthcare, as a way of consolidating primary healthcare. ${ }^{2}$

Despite difficulties in the early years of implantation, the FHS has spread rapidly in the country, especially after 1998, with the implementation of the Basic Care Floor (BCF). ${ }^{3}$ The numerical expansion of Family Health teams has brought various gains for the population, with greater access to primary care and a positive impact on health indicators. ${ }^{4-6}$

The consolidation of this new healthcare strategy has the potential to strengthen primary care, helping to confront health problems and reduce inequality.7 However, its robust consistent growth has deep implications for evaluation processes, analyses of impact on morbidity and mortality and organization of care practices.

In the case of evaluation of the effectiveness of healthcare within the FHS there have been important studies of Hospitalizations for Conditions Susceptible to Primary Care (HCSPCs). Such conditions are diseases that, if well attended and cared for at the first level of care, do not require hospitalization or require it far less. ${ }^{8}$ It can thus be understood that the identification of many hospitalizations for conditions susceptible to primary care may be the result of deficiencies in the performance of primary healthcare services provided, whose failings range from access to the service to its capacity to produce results. HCSPCs are thus an important assessment indicator for access to and quality of primary care. ${ }^{8}$ There is expected to be an intrinsic and inversely proportionate correlation between the expansion of the FHS and HCSPCs, in so far as an increase in the number of FHS teams and coverage should be reflected in a proportionately reduced number of HCSPCs.

In Brazil, the use of HCSPCs has become a frequent topic in scientific publications, with an emphasis on ecological studies analyzing the evolution of hospitalizations among adults. ${ }^{9}$ There are few studies that address pediatrics and adolescents. ${ }^{10-12}$ Studies of this age group are important since, different from adults, acute conditions predominate in this sector of the population. There are also distinct standards for younger (breastfeeding) children and for adolescents. 10 The aim of the present study is to describe the evolution of HCSPCs in the population aged under 20 years between 1999 and 2007 in the State of Minas Gerais, correlating this with FHS coverage of the population over the same period.

\section{Methods}

This was an ecological analytical study. The target population was individuals aged between 0 and 19 years. The study included data for all individuals aged under 20 years residing in Minas Gerais who were hospitalized during the period under study. For more detailed analysis, the group was subdivided into the following age groups: 0 - 4 years, 5 - 9 years and $10-19$ years, following the age division available in the data source. 13 All data were obtained from the National Health System Information Department (Datasus) which provides information on admissions to public and private hospitals operating within the SUS, from Hospital Admission Authorizations (HAA), through the Hospital Information System (HIS).

The period covered stretched from 1999 to 2007. The aim of these temporal cut-off points was to work with more uniform data, since, as of 1999, the Ministry of Health determined that authorizations of hospital admissions should be filled in using the Tenth International Classification of Diseases codes (ICD-10) instead of the 9th International Classification of Diseases (ICD-9) which had been used up to then. On the other hand, 2008 saw the introduction of a new uniform table of procedures for filling in the HAA (GM/MS $n^{\circ} 154127$ June 2007), which may also generate misleading analyses.

To calculate hospitalization rates, the number of hospitalizations was divided by population estimates for each year for the target population, obtained from the Brazilian Institute of Geography and Statistics (IBGE), and multiplying the final result by a constant of 1,000 . FHS coverage was measured using data retrieved from the website of the Department of Basic Care/Secretary of Healthcare/ Ministry of Health. ${ }^{13}$

Analysis of the correlation between hospitalization rates and FHS coverage throughout the State was carried out using Pearson's Correlation Coefficient ("r"), with a level of significance of $5 \%$ $(p<0.05)$. Calculations were performed on electronic spreadsheets and using the Statistical Package for the Social Sciences (SPSS), Version 17.0. 


\section{Results}

The evolution of hospitalization rates among individuals aged under 20 years in Minas Gerais in the period under study is presented in Table 1, with details for the respective age groups. It can be seen that, during the period under observation, including the first and last year of the time series, HCSPC rates among those aged between 0 and 4 years declined from 34.94 to $28.27 / 1000$ inhabitants, amounting to a reduction of $19.1 \%$. In this same age group, the hospitalization rate for other conditions saw a drop from 69.04 to $42.87 / 1000$ inhabitants, amounting to a decrease of $37.91 \%$. HCSPCs increased proportionally from $33.6 \%$ to $39.74 \%$, for hospitalizations as a whole.

It should be noted that, for the $5-9$ and $10-19$ year age groups, rates varied less between the first and last year of the series studied. Among those aged 5 - 9 years, HCSPCs fell from 6.35 to $6.31 / 1000$ inhabitants and among those aged $10-19$ years, from 3.89 to $3.17 / 1000$ inhabitants.

Table 2 presents an analysis of the correlation between FHS coverage and the total number of HCSPCs during the period studied. It can be seen that there was an inverse or negative correlation for all the rates calculated across the series (1999 2007). However, the correlation was only significant in the 0 - 4 and 5 - 9 year age groups for hospitalizations not susceptible to primary care and, in the 10 19 year group for HCSPCs.

For the three age groups evaluated, it was found that some diseases were repeated as groups of causes with the highest frequency. The main causes of HCSPC were infectious gastroenteritis, bacterial pneumonia, asthma, infections of the urinary tract, diseases of the lower airways and epilepsy.

Figure 1 shows the distribution of groups of causes of HCSPC. It can be seen that the five main causes account for $90.8 \%$ in the youngest, $87.3 \%$ in the intermediate group and $68.8 \%$ of adolescents. In particular, gastroenteritis and its complications, asthma and bacterial pneumonia accounted for more than $50 \%$ of HCSPCs throughout the period.

Figure 2 shows the behavior of the three main causes of HCSPC in the population studied between 1999 and 2007. It can be seen that the rate for gastroenteritis was $477.75 / 1000$ inhabitants in the first year studied and fell to 270.21/1000. Asthma maintained a roughly constant rate throughout the period. The rate in 1999 was 206.80 and 191.27/1000 inhabitants in 2007. Pneumonia increased greatly from 75.70 to $282.19 / 1000$ inhabitants, a rise of $73.2 \%$

\section{Discussion}

In the present study, analysis of the HCSPC trend found a decrease in hospitalization rates, which concurs with the behavior observed for HCSPCs in other studies with different age groups and time frames. $9,14-16$ However, it is important to note that the studies that evaluated the pattern of hospitalizations in adult patients found a more marked drop in HCSPC rates. ${ }^{14-17}$

For the population studied, it was found that, in fact, there was a tendency for all rates to decline, but this was clearest only in the last four years of the series. A similar finding appeared in a study conducted in the State of Pernambuco, for the period between 1999 and 2009, in a population of children aged under five years, in which almost half of hospitalizations were attributed to conditions susceptible to primary care. 11

In Brazil, there are still few studies of HCSPCs for the population of children and adolescents and those that exist are not consistent in terms of the age groups studied or the methodology employed. This, in combination with regional particularities and socioeconomic influences, may explain the distinct results. While, in the present study, the percentage of HCSPCs in children aged 0-4 years always lay between 30 and $40 \%$ in the years under investigation and in the 5 to 9 year group, the mean was lower than $30 \%$ and in the $10-19$ group, the percentage of HCSPCs did not exceed 20\%, in the State of Piauí, roughly half of hospitalizations in children under five years of age, over ten years, were attributed to conditions susceptible to primary care. 12 Pernambuco also saw a higher proportion of HCSPCs in this age group, dropping $42.8 \%$ between 2003 and 2009.11

Analysis of the correlation between FHS coverage and rates of hospitalization showed that the expansion of the FHS care network has not had a significant effect in terms of reducing rates of HCSPCs among those aged under nine years, even though the relation observed may be inverse. This correlation was significant for those aged under five years and between 5 and 9 years for hospitalizations not susceptible to primary care and for the 10-19 age group only for HCSPCs. These findings suggest a one-off, fortuitous correlation. It is not possible to establish associations of causality, as the ecological study deals with hospitalizations not susceptible to primary care. The finding of an inverse and significant correlation for HCSPCs in the 10-19 age group requires further investigation, since adolescents infrequently seek out health services and it is not 


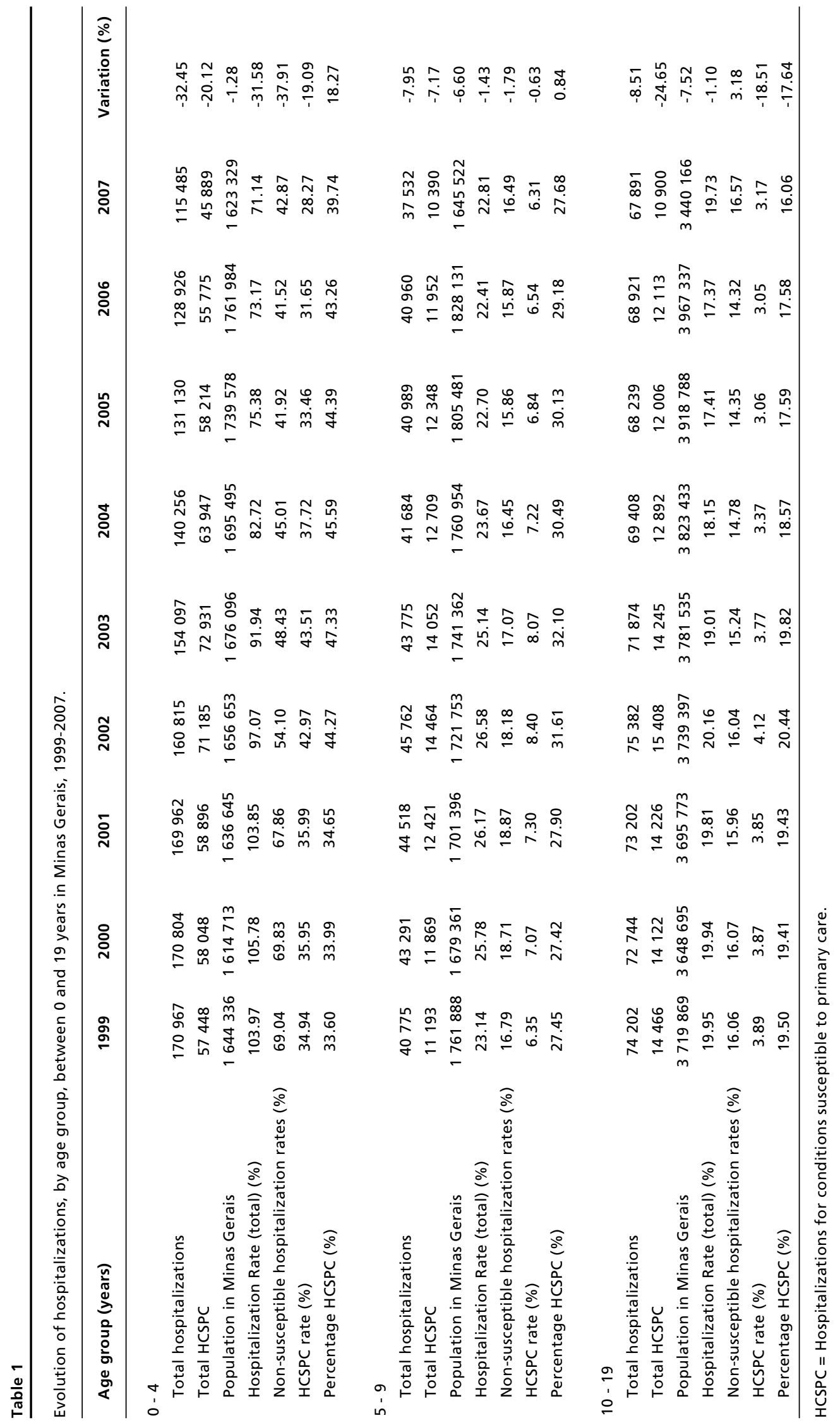




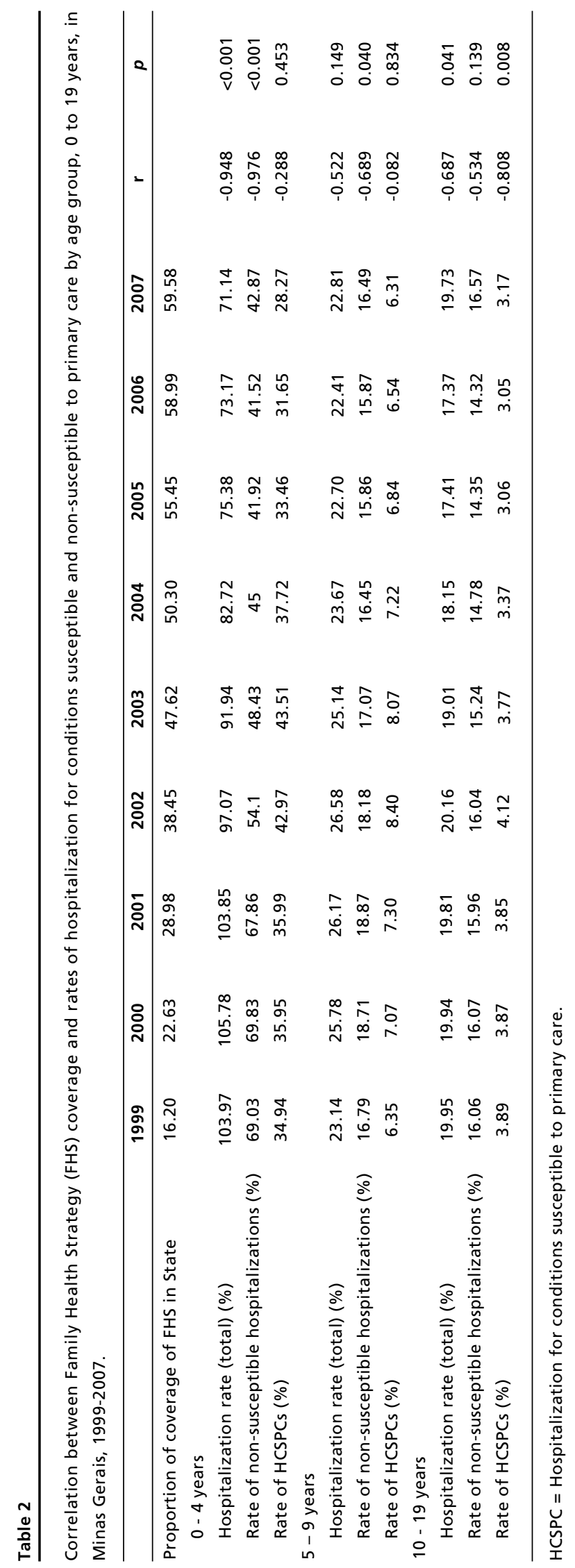


Distribution of main groups of Hospitalizations for Conditions Susceptible to Primary Care, by age group. Minas Gerais, 1999-2007.

\section{0 to 4 age range}

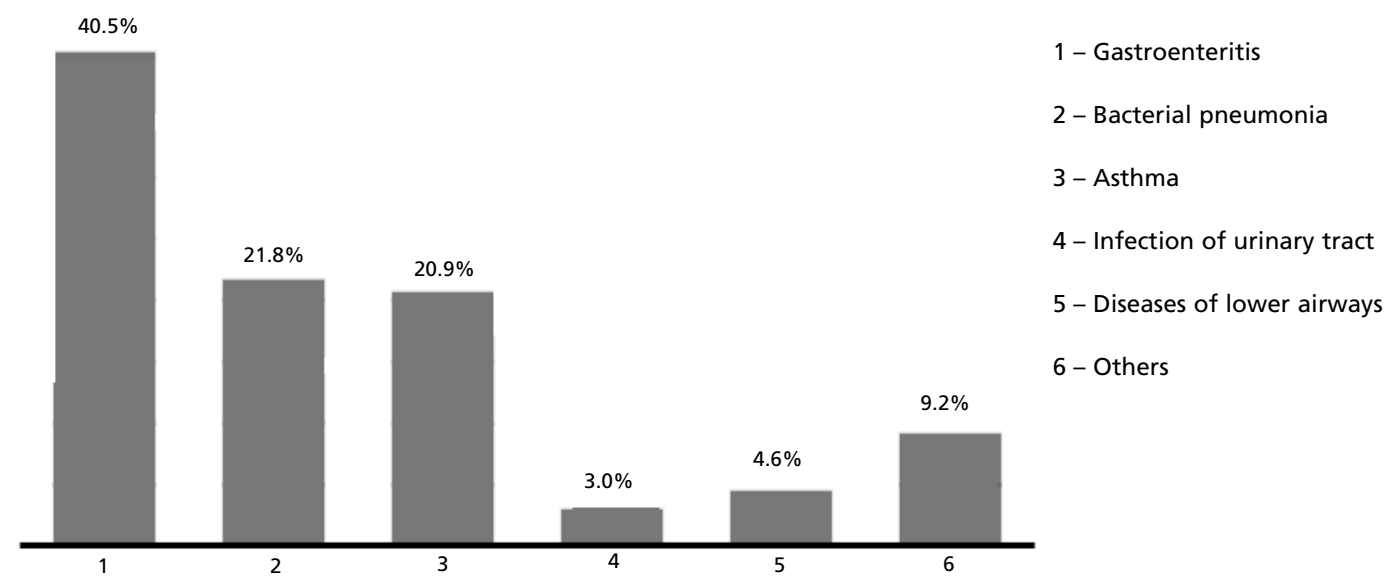

5 to 9 age range

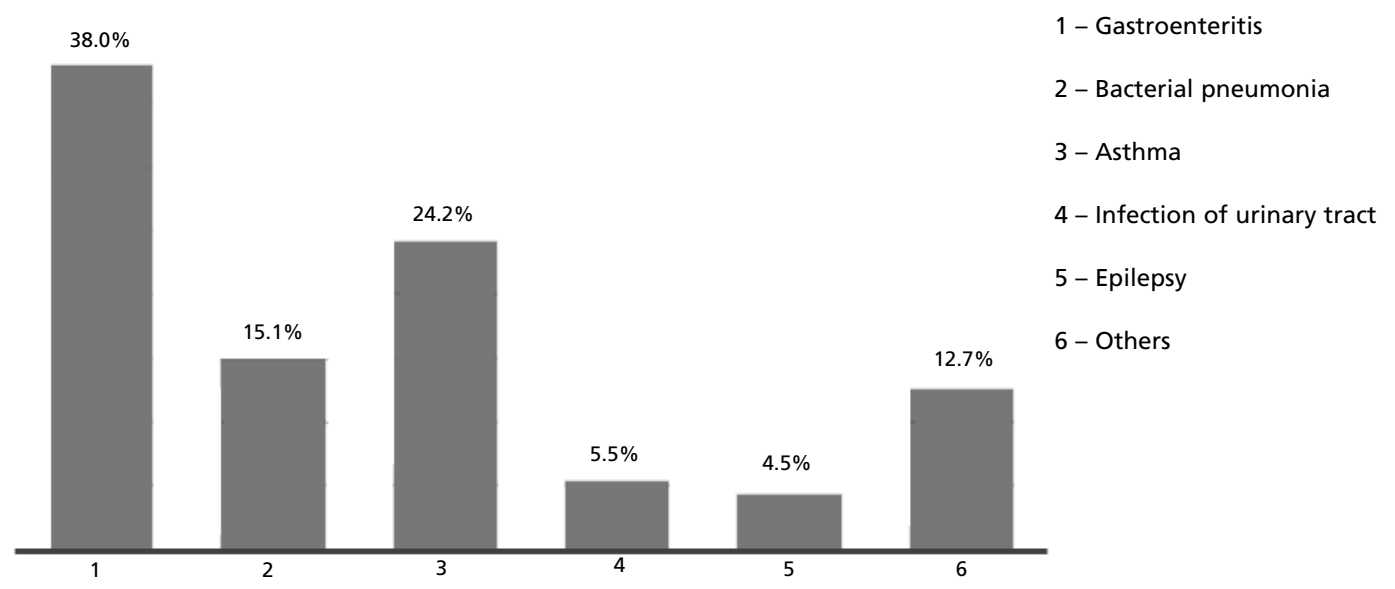

10 to 19 age range

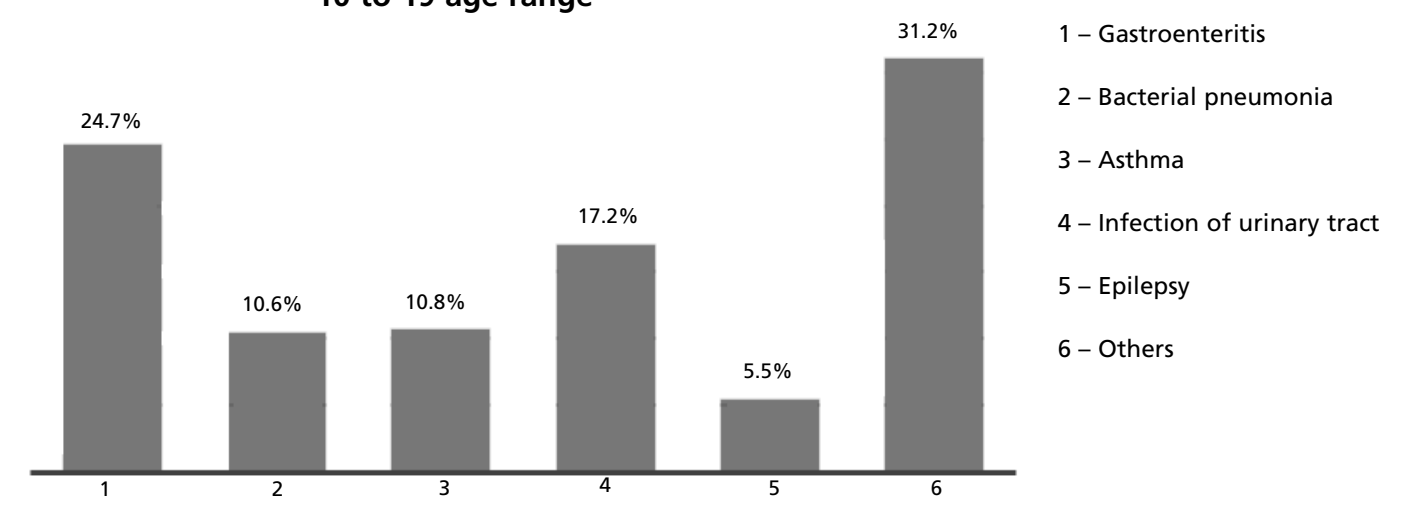


Figure 2

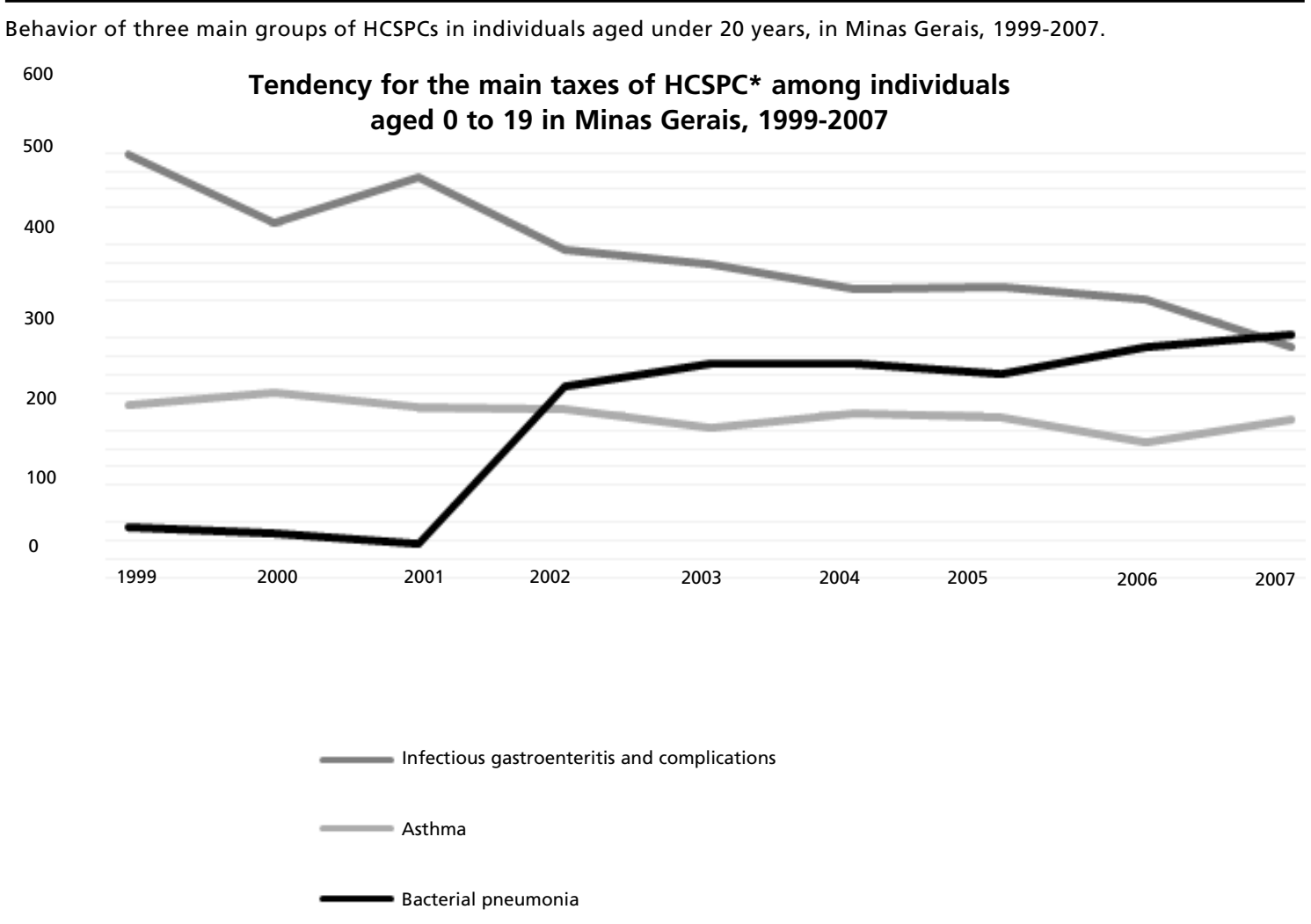

(*) Rates are expressed in number of hospitalizations/1,000 inhabitants.

$\mathrm{HCSPC}=$ Hospitalization for conditions susceptible to primary care.

possible to attribute this result to a relation of causality. Furthermore, this is one of the age groups in which there are fewest hospitalizations. 18 According to a 2010 study of adolescents, the hospitalization rate did not exceed a tenth that of the general population in the year under study. 19

Some studies have pointed to a significant inverse correlation between increased FHS coverage and a reduction in rates of HCSPCs in the adult population. ${ }^{14-17}$ However, this relation has not been reported consistently in other studies and each Brazilian State has its own peculiarities. ${ }^{20}$ A study in the south of Minas Gerais found the rates for two time periods to behave differently for different age groups. ${ }^{21}$ In another study, divergent behavior was found for some conditions susceptible to primary care, including an increase in some rates and thus pointing to the need to reorganize FHS teams to improve the indicators observed. 22

The results with different tendencies for different regions may suggest limitations on health teams in provision of child healthcare, although the multicausal nature of the event studied should be taken into consideration. The analyses also point out the need for more in-depth reflection on the limitations of the HCSPC indicator and the determinants of hospitalizations for avoidable causes. Some characteristics of primary care may influence the behavior of the team regarding this and other indicators, such as the size of the enrolled population, the continuity of care, the characteristics and qualifications of the health team and the local physician. ${ }^{23}$ Other authors have discussed the limitations of the indicator, pointing to characteristics of the population group involved and factors relating to individuals. ${ }^{8}$ Factors such as very low household income and very young or very advanced age, for example, may be intervening conditions that increase the risk of hospitalization. A study conducted in Minas Gerais found a high prevalence of HCSPCs attended primarily by the emergency care unit, which, in the view of these authors, highlights the excessive load borne by 
emergency services to the detriment of longitudinal primary health care. 24

Reflection on the relation between FHS coverage and HCSPCs should also take into account the possibility that a low population coverage does not affect some indicators. Studies in Pernambuco11 and Piauí12 reported a significant inverse correlation where, in the period studied, there was FHS coverage of nearly $100 \%$.

The present study came up with findings similar to various other studies in the area regarding the main groups of diseases that generate HCSPCs. $10,18,25,26$ According to the national literature, the most prevalent diseases among children aged 0-4 years in the Southeast are infectious gastroenteritis and its complications and bacterial pneumonia.9,26 A study in Piauí of the 1 - 4 year age group, between 2000 and 2010 found the main causes to be related to infectious and parasitic diseases, respiratory disorders and diseases of the digestive tract in that order.12 An international study found the six main diagnoses in a population aged under 18 years to be asthma, dehydration/gastroenteritis, pneumonia, convulsions, skin infection, and infection of the urinary tract, which accounted for $90 \%$ of hospitalizations. 27 In short, acute conditions or their complications predominate in children, which is different from the pattern for other age groups. 26

Analysis of the groups of diseases that generate HCSPCs showed that, for the age group studied, gastroenteritis, bacterial pneumonia and asthma accounted for more than half of HCSPCs. There is, therefore, a need for primary care teams to be more efficient in preventing and treating these diseases.

It is worth noting each of these diseases behaved differently: there were reduced rates for gastroenteritis, while bacterial pneumonia increased and asthma remained practically unchanged. Gastroenteritis is closely related to sanitary education conditions and should therefore tend to decline sharply with adequate prevention and promotion. Complications should also be reduced if the condition is attended to in an adequate and timely fashion. This decline in gastroenteritis has also been found in other studies. 11,12,14,26 A study of a number of cities in Bahia showed that the rate of hospitalizations for gastroenteritis declined sharply and is associated with increased FHS coverage. However, this association did not persist after multivariate analysis, when data were adjusted in relation to variables such as solid waste collection, sanitary sewerage and water supply. 28
Respiratory diseases are common causes of child hospitalizations and this is backed up by the present study. A national study conducted between 1998 and 2007, in children aged $1-4$ years, showed that diseases of the respiratory apparatus $(40.3 \%)$ were the main cause of hospitalizations, followed by infectious and parasitic diseases $(21.6 \%)$, and diseases of the digestive tract $(5.5 \%) .{ }^{25}$ The increased rate for bacterial pneumonia in particular is an especially worrying sign. This result has also been reported in other studies.22,29 Some authors have noted that this increase coincides with changes in payments for HAA procedures, with an increase of $124.8 \%$ for this disease. ${ }^{29}$

The unchanged rates for asthma have been associated with patient adherence, the qualification of professional and/or difficulty of access to adequate treatment. A review study of the subject concluded that the FHS teams have limitations in managing asthma, with an inadequate physical space and lack of commitment and knowledge on the part of professionals regarding the disease. 30

The results of the present study should be interpreted with various limitations in mind. It is an ecological study, working with secondary data, which, in some situations, may raise doubts as to its reliability. But it should be noted that a study of tendencies, with the quantity of data covered, is difficult to carry out in any other way. On the other hand, the volume of data provides a high level of representativeness for the location studied. It is also worth noting that the unit of analysis was the whole State of Minas Gerais, in all the social, political, cultural, environmental and economic diversity of its 853 municipalities. Very significant differences between the municipalities and regions of the State may interfere differently with the impact of extended FHS coverage. This, however, was not the aim of the present study and further studies need to be conducted in this field to improve understanding of the phenomenon under study.

In conclusion, the present study revealed that, in Minas Gerais, from 1999 to 2007, for the population aged 0 to 19 years, there was a decline in avoidable hospitalizations. Over the same period, there was a significant increase in Family Health Strategy coverage but this was not significantly correlated with the behavior of child HCSPCs. This suggests the interference of other variables in the process of child hospitalization and the need for public policy to improve access to healthcare for children and adolescents and to strengthen primary care. 


\section{References}

1. Rosa WAG, Labate RC. Programa Saúde Da Família: A Construção de um novo modelo de assistência. Rev LatinoAm Enfermagem. 2005; 13 (6): 452-67

2. Starfield B. Atenção Primária: equilíbrio entre necessidades de saúde, serviços e tecnologia. Brasília: UNESCO, Ministério da Saúde; 2002. 726 p.

3. Brasil. Ministério da Saúde. Secretaria de Atenção à Saúde. Departamento de Atenção Básica. Programa Saúde da Família: ampliando a cobertura para consolidar a mudança do modelo de Atenção Básica. Rev Bras Saúde Mater Infant. 2003; 3 (1): 113-25.

4. Rasella D, Aquino R, Barreto ML. Reducing childhood mortality from diarrhea and lower respiratory tract infections in Brazil. Pediatrics. 2010; 126: 534-40.

5. Victora CG, Aquino EML, Leal MC, Monteiro CA, Barros FC, Szwarcwald CL. Maternal and child health in Brazil progress and challenges. Lancet. 2011; 377 (9779): 1863 76

6. Sala A, Luppi CG, Simões O, Marsiglia RG. Integralidade e atenção primária à saúde: avaliação na perspectiva dos usuários de unidades de saúde do município de São Paulo. Saúde Soc. 2011; 20 (4): 948-60.

7. Alves H, Escorel S. Processos de exclusão social e iniquidades em saúde: um estudo de caso a partir do Programa Bolsa Família, Brasil. Rev Panam Salud Publica. 2013; 34 (6): 429-36

8. Alfradique ME, Bonolo PF, Dourado I, Lima-Costa MF, Macinko J, Mendonça CS, et al. Internações por condições sensíveis à atenção primária: a construção da lista brasileira como ferramenta para medir o desempenho do sistema de saúde (Projeto ICSAP - Brasil). Cad Saúde Pública. 2009; 25: $1337-49$.

9. Pereira FJR, Silva CC, Lima Neto EA. Condições Sensíveis à Atenção Primária: uma revisão descritiva dos resultados da produção acadêmica brasileira. Saúde Debate. 2014; 38 : 331-42.

10. Caldeira AP, Fernandes VBL, Fonseca WP, Faria AA Internações pediátricas por condições sensíveis à atenção primária em Montes Claros, Minas Gerais, Brasil. Rev Bras Saúde Matern Infant. 2011; 11 (1): 61-71.

11. Carvalho SC, Mota E, Dourado I, Aquino R, Teles C, Medina MG. Hospitalizations of children due to primary health care sensitive conditions in Pernambuco State, Northeast Brazil. Cad Saúde Pública. 2015; 31 (4): 744-54.

12. Barreto JOM, Nery IS, Costa MSC. Estratégia Saúde da Família e internações hospitalares em menores de 5 anos no Piauí, Brasil. Cad Saúde Pública. 2012; 28 (3): 515-26.

13. Brasil. Ministério da Saúde. Departamento de Informática do SUS (DATASUS). Informações de saúde: Epidemiológicas e Morbidade. [acesso em mar 2013]. Disponível em <www.datasus.gov.br $>$

14. Boing AF, Vicenzi RB, Magajewski F, Boing AC, MorettiPires RO Peres KP, Lindner SR, Peres MA. Redução das Internações por Condições Sensíveis à Atenção Primária no Brasil entre 1998-2009. Rev Saúde Pública. 2012; 46 (2): 359-66
15. Campos AZ, Theme-Filha MM. Internações por condições sensíveis à atenção primária em Campo Grande, Mato Grosso do Sul, Brasil, 2000-2009. Cad Saúde Pública. 2012; 28 (5): 845-55.

16. Mendonça SS, Albuquerque EC. Perfil das internações por condições sensíveis à atenção primária em Pernambuco, 2008 a 2012. Epidemiol Serv Saúde. 2014; 23 (3): 463-74.

17. Maciel AG, Caldeira AP, Diniz FJLS. Impacto da Estratégia Saúde da Família sobre o perfil de morbidade hospitalar em Minas Gerais. Saúde Debate. 2014; 38: 319-30.

18. Junqueira RMP, Duarte EC. Internações hospitalares por causas sensíveis à atenção primária no Distrito Federal, 2008. Rev Saúde Pública. 2012; 46 (5): 761-68.

19. Dornellas PMR. Adolescentes no Brasil: internações hospitalares no Sistema Único de Saúde [dissertação]. Londrina: Universidade Estadual de Londrina; 2011.

20. Ceccon RF, Meneghel SN, Viecili PRNo. Internações por condições sensíveis à atenção primária e ampliação da Saúde da Família no Brasil: um estudo ecológico. Rev Bras Epidemiol. 2014; 17 (4): 968-77.

21. Rodrigues-Bastos RM, Campos EMS, Ribeiro LC, Firmino RUR, Bustamante-Teixeira MT. Internações por condições sensíveis à atenção primária em município do sudeste do Brasil. Rev Assoc Med Bras. 2013; 59 (2): 120-7.

22. Avelino CCV, Goyatá SLT, Nogueira DA, Rodrigues LBB, Siqueira SMS. Qualidade da atenção primária à saúde: uma análise segundo as internações evitáveis em um município de Minas Gerais, Brasil. Ciênc Saúde Coletiva. 2015; 20 (4): 1285-93

23. Nedel FB, Facchini LA, Martín M, Navarro A. Características da atenção básica associadas ao risco de internar por condições sensíveis à atenção primária: revisão sistemática da literatura. Epidemiol Serv Saúde. 2012; 19 (1): 61-75

24. Cardoso CS, Pádua CM, Rodrigues-Júnior AA, Guimarães DA, Carvalho SF, Valentin RF, Abrantes R, Oliveira CDL. Contribuição das internações por condições sensíveis à atenção primária no perfil das admissões pelo sistema público de saúde. Rev Panam Salud Publica. 2013; 34 (4) 227-34.

25. Oliveira BRG, Viera CS, Collet N, Lima RAG. Causas de hospitalização no SUS de crianças de zero a quatro anos no Brasil. Rev Bras Epidemiol. 2010; 13 (2): 268-77.

26. Moura BLA, Cunha RC, Aquino R, Medina MG, Mota ELA, Macinko J, Dourado I. Principais causas de internação por condições sensíveis à atenção primária no Brasil: uma análise por faixa etária e região. Rev Bras Saúde Matern Infant. 2010; 10 (Supl. 1): S83-S91.

27. Flores G, Abreu M, Chaisson CE, Sun D. Keeping children out of hospitals: parents' and physicians' perspectives on how pediatric hospitalization for ambulatory care sensitive conditions can be avoided. Pediatrics. 2003; 112: 1021-30.

28. Monahan LJ, Calip GS, Novo PM, Sherstinsky M, Casiano M, Mota E, Dourado I. Impact of the Family Health Program on gastroenteritis in children in Bahia, Northeast Brazil: an analysis of primary care-sensitive conditions. J Epidemiol Glob Health. 2013; 3 (3): 175-85 
29. Rosa AM, Ignotti E, Hacon SS, Castro HA. Análise das internações por doenças respiratórias em Tangará da Serra Amazônia Brasileira. J Bras Pneumol. 2008; 34 (8): 57582.

Received on december 14, 2015

Final version submitted on march 14, 2016

Approved on april 7, 2016
30. Leal RCAC, Braile DM, Souza DRS, Batigália F. Modelo assistencial para pacientes com asma na atenção primária. Rev Assoc Med Bras. 2011; 57 (6): 697-701. 